\title{
Hill to Plain: Causes and Impacts of Internal Migration of Indigenous Peoples in Bangladesh
}

\author{
Basu Mittra Chakma*, Asma Akter Akhy \\ Department of Sociology, University of Chittagong, Chittagong, Bangladesh \\ Email: ${ }^{*}$ mukambay@yahoo.com, Akhy777@gmail.com
}

Received 9 September 2015; accepted 17 October 2015; published 20 October 2015

Copyright (C) 2015 by authors and Scientific Research Publishing Inc.

This work is licensed under the Creative Commons Attribution International License (CC BY).

http://creativecommons.org/licenses/by/4.0/

(c) (i) Open Access

\begin{abstract}
Various factors are related in internal migration of indigenous peoples from their ancestral places, that is hill, to the plain areas. This article aims to find out the pull and push factors of the indigenous migration. The study has been conducted in Chittagong Export Processing Zone at Chittagong, Bangladesh. The major finding of the study is that indigenous peoples are greatly migrated to plain places for economic reason voluntarily. It also indicates that among 14 indigenous groups living in the Chittagong Hill Tracts (CHT), mainly Chakma people have been migrated in large volume. It finds that women are clearly ahead than their counterparts in migrating to the plain areas. The migrant's traditional culture and customs are greatly affected after their migration which is highlighted in this paper.
\end{abstract}

\section{Keywords}

Hill to Plain, Indigenous Peoples, Internal Migration, Chittagong Hill Tracts

\section{Introduction}

From ancient period, migration has been considered as an important phenomenon around the world. In human history, people have been moving from one area to another for various causes. It is often defined as a form of geographical or spatial mobility, which involves a change of usual residence of a person between clearly defined geographical units (Gautam, 2005: 1). When a person or group of person move from one area to another can be called migration in geographical perspectives. According to International migration report 2002, it has been estimated that around 175 million people currently reside in a country other than where they were born, equivalent

\footnotetext{
"Corresponding author.
} 
to around 3 percent of the world population (Giddens, 2006). In twenty-first century, mainly because of rapid globalization and industrialization, people are moving within inland and cross own state sovereign border more easily than ever. In the period of "age of migration" the marginalized peoples of a country, like ethno-religious minority, tribal and indigenous peoples had also been influenced to migrate for various political and economic causes. This article tries to concentrate on internal migration of indigenous peoples ${ }^{1}$ from Chittagong Hill Tracts $(\mathrm{CHT})^{2}$ to plain ${ }^{3}$ districts in Bangladesh. The CHT has its distinct character and it is around one-tenth of Bangladesh. It has distinct character not only for its hilly landscape but also for ethnicity and culture of its 14 different indigenous ethnic groups. In recent years internal migration of indigenous peoples from the CHT to plain areas, especially to the industrialized areas, has been significant. Historically the migration of these peoples has been occurred in four different phases:
A. Societal
B. Developmental
C. Communal
D. Political

It has been noticed in the first phase of indigenous peoples internal migration to plain areas that the CHT people has developed their own cultivation system which is widely known as "Jum"4 cultivation or shifting/Sweden cultivation. Movement in household level from hill to hill searching cultivable hilly land for Jum cultivation was a historical and societal part of indigenous migration. They were migratory in culture because of this cultivation system.

In the second phase the indigenous peoples have been in developmental paradox. It was development for underdevelopment. Indigenous peoples have been forcefully migrated due to state governed developmental project. During Pakistan period, basically in 1960s, government built the Captai hydro-electric dam on Karnafully River which flooded $1036 \mathrm{sq}$. km of lands and submerged 54\% (54000 acres) of the arable land and displaced about 100,000 indigenous peoples from their ancestral land (Chakma, 2009). Due to the project about 40,000 indigenous peoples were forced to migrate into India and 20,000 into Myanmar but a significant portion of indigenous peoples migrated to other hill areas of the CHT (PCJSS, 2013).

In the communal phase, large amounts of Bangali were settled into the CHT that caused forced indigenous migration internally. In the period of 1951-1960 Pakistan government settled 93,000 of Bangali into CHT and begun to grab the ancestral land of indigenous peoples that caused internal migration of indigenous peoples within the CHT in different region. In Bangladesh period, from 1979 to 1984, Zia govt. began state sponsored migration of Bangali into the CHT by declaring that each Bangali settler family would be given 7.5 acres of land. In that period 400,000 Bangali Muslim from different plain districts were settled over the indigenous land (Mohsin, 1997). As no cultivable land was vacant for settlement, these settlers eventually grabbed the ancestral land of indigenous peoples. A large number of indigenous peoples mainly migrated to Arunachal, Mizoram and other states of India and many were displaced within CHT. In this phase they hardly thought of migrating to plain areas (Chowdhury \& Chakma, 2015).

In the fourth phase, after signing The CHT Peace Accord in 1997, a historical change was noticed in the trend of indigenous peoples' internal migration. Depending on state sponsored rehabilitation measure promised by the Bangladesh govt., a large volume of indigenous peoples who were forcefully migrated to India returned to the CHT. Though they didn't get returned their land as per the CHT accord but the political situation of the CHT became comparatively stable. In this phase indigenous peoples got a suitable time to be institutionally educated. As there were no industrial bases in the CHT area to accommodate the educated and less-educated people, they started migrating to other plain industrialized areas of Bangladesh. Again due to non-implementation of peace accord and presence of vulnerable political situation, a huge number of indigenous people have been migrated to plain areas of Bangladesh.

This paper aims to find out the push and pull factors of indigenous peoples internal migration from the CHT area to plain arena in different phases. Everett Lee's push-pull factors have been used in analyzing the causes related in the internal migration of indigenous peoples. This study has been conducted to focus on major two objectives. Firstly, to find out the causes of internal migration of indigenous peoples from the CHT and secondly to search the impact on socio-cultural and demographic life of indigenous peoples due to migration. Very few

\footnotetext{
${ }^{1}$ The 14 distinct ethnic communities residing in the CHT.

${ }^{2} \mathrm{CHT}$ consists of three hill districts (Rangamati, Khagrachori, and Bandarban) situated on the southern part of Bangladesh.

${ }^{3}$ Bangladeshi inlands excluding the CHT.

${ }^{4}$ Popular traditional cultivation system in the CHT.
} 
earlier studies on the CHT indigenous peoples focused on indigenous migration in Bangladesh that enriches rationality of this paper.

\section{Methodology}

The study has been conducted in quantitative manner. For collecting data a survey was conducted at Barrister College area in the Chittagong Export Processing Zone (CEPZ) in Bangladesh. According to local data, the CEPZ, an important industrialized zone in Bangladesh, is the largest host area of migrant indigenous peoples. Around 10,000 indigenous migrants have been found residing at Barrister College area. 250 respondents were selected following random and accidental method. The survey was conducted in the last week of April, 2015 to collect primary data from the study area. The questionnaire of data collection was formulated by both 9 open ended and 78 close ended questions. In this article deductive method was followed and the migration trends of indigenous peoples have been narrated according to Everett Lee's (1966) push-pull factors. Relevant data have been used from secondary sources including books, journals, little magazine, government and non-government report, websites, articles, newspapers etc.

\section{Profile of Respondents}

Respondents have been found came from various socio-economic backgrounds and ethnic minority groups. Considering their ethnic composition, $82.0 \%$ of the migrants are from Chakma ethnic group and $10.8 \%$ are found from Marma. Migrants from Tripura and Tancangya are not significant. As the data shows, female (52.8\%) are found more migrated than their counterparts. Most of the migrants (56.8\%) are found migrated from Rangamati hill district and only 9.2\% are from Bandarban district. Collected data shows that maximum migrants, both male and female, are young in age. 33.6\% of total respondents are in age group (21 - 25). 24\% migrants are from 26 - 30 age group and $21.2 \%$ are from 19 - 20 age group. $44.8 \%$ of migrants passed secondary school and $34.4 \%$ higher secondary level. $74.4 \%$ of these migrants are garment workers living in this industrial area. 64\% of the respondents reported that they have no more than 2 - 3 members in their family. More than half of migrants (53.2\%) stated their monthly income around 5001 - 10,000 BDT while 24.8\% migrants earn 3001 - 5000 BDT in a month. A few migrants (3.6\% only) earn more than 20,000 BDT. 39.6\% of total respondents reported that the tenure of their migration is 2 - 3 years. Only $11.2 \%$ respondents reported that the tenure of their migration is more than 10 years (see Table 1 ).

\section{Causes of Indigenous Internal Migration}

Various reasons have been found responsible for the internal migration of the indigenous peoples of CHT. These reasons are categorized under push and pull factors. This study has found that the pull factors as well as the push factors are equally responsible for this indigenous internal migration.

\subsection{Push Factors}

The various push factors that the study has identified are the lack of employment opportunities, land grabbing, communal harassment, torture by the law enforcing agencies and the intra-ethnic conflict in the CHT (see Table 2). It is observed that, the indigenous young educated male and female are not interested in their traditional professions like Jum cultivation or agriculture based activities. Scarcity of employment opportunities in CHT is the prime push factor behind the indigenous peoples' internal migration. The CHT is one of the most impoverished regions of the country with few industrial infrastructures. Since there is no alternative way to hard-cash income in the region except agricultural activities and government jobs, the vast majority of the total respondents (44.8\%) had to migrate from their native place

Agricultural sector is one of the most important income sources of the peoples of the CHT. But, the amount of arable land available to the indigenous peoples has decreased because of land grabbing by the security forces, Bengali settlers and government agencies. $19.6 \%$ of the total respondents reported that they migrated due to the loss of their arable land. Among them, 42.7\% lost 1 - 5 acres while $13.4 \%$ lost 6 - 10 acres of land to the land grabbers.

According to the collected data, other reasons of internal migration are communal attack on indigenous peoples, political instability in CHT and intra-ethnic conflicts among indigenous peoples. 14\% respondents mi- 
Table 1. Socio-economic condition of respondents.

\begin{tabular}{|c|c|c|c|c|c|c|c|c|c|c|c|}
\hline \multirow{3}{*}{$\begin{array}{c}\text { Socio-economic variables } \\
\text { Ethnic groups } \\
\text { Sex } \\
\end{array}$} & \multicolumn{10}{|c|}{$\mathrm{N}=250$} & \multirow{3}{*}{$\%$} \\
\hline & \multicolumn{2}{|c|}{$\begin{array}{c}\text { Chakma } \\
82.0 \%\end{array}$} & \multicolumn{2}{|c|}{$\begin{array}{c}\text { Marma } \\
10.8 \%\end{array}$} & \multicolumn{2}{|c|}{$\begin{array}{c}\text { Tripura } \\
2.8 \%\end{array}$} & \multicolumn{2}{|c|}{$\begin{array}{c}\text { Tanchangya } \\
2.8 \%\end{array}$} & \multicolumn{2}{|c|}{$\begin{array}{c}\text { Others } \\
1.6 \%\end{array}$} & \\
\hline & $\begin{array}{c}\mathrm{M} \\
(39.2 \%)\end{array}$ & $\begin{array}{c}\mathrm{F} \\
(42.8 \%)\end{array}$ & $\begin{array}{c}\mathrm{M} \\
(04 \%)\end{array}$ & $\begin{array}{c}F \\
(6.8 \%)\end{array}$ & $\begin{array}{c}\mathrm{M} \\
(1.2 \%)\end{array}$ & $\begin{array}{c}F \\
(1.6 \%)\end{array}$ & $\begin{array}{c}\mathrm{M} \\
(1.6 \%)\end{array}$ & $\begin{array}{c}F \\
(1.2 \%)\end{array}$ & $\begin{array}{c}\mathrm{M} \\
(1.2 \%)\end{array}$ & $\begin{array}{c}F \\
(0.4 \%)\end{array}$ & \\
\hline \multicolumn{12}{|l|}{ Home district } \\
\hline Khagrachari & 35 & 33 & 04 & 07 & 03 & 03 & 00 & 00 & 00 & 00 & 85 (34\%) \\
\hline Rangamati & 63 & 71 & 01 & 01 & 00 & 01 & 03 & 01 & 01 & 00 & $142(56.8)$ \\
\hline Bandarban & 00 & 03 & 05 & 09 & 00 & 00 & 01 & 02 & 02 & 01 & $23(9.2)$ \\
\hline \multicolumn{12}{|l|}{ Age group } \\
\hline 14 - 18 & 06 & 03 & 00 & 00 & 01 & 00 & 01 & 00 & 01 & 00 & $12(4.8 \%)$ \\
\hline $19-20$ & 23 & 25 & 01 & 02 & 00 & 01 & 00 & 01 & 00 & 00 & $53(21.23 \%)$ \\
\hline $21-25$ & 30 & 34 & 05 & 07 & 01 & 02 & 01 & 02 & 01 & 01 & 84 (33.6\%) \\
\hline $26-30$ & 21 & 28 & 01 & 06 & 01 & 01 & 01 & 00 & 01 & 00 & 60 (24\%) \\
\hline $31-40$ & 11 & 13 & 02 & 02 & 00 & 00 & 01 & 00 & 00 & 00 & $29(11.6 \%)$ \\
\hline $40+$ & 07 & 04 & 01 & 00 & 00 & 00 & 00 & 00 & 00 & 00 & $12(4.8)$ \\
\hline \multicolumn{12}{|l|}{ Educational Qualification } \\
\hline Secondary & 54 & 44 & 02 & 06 & 01 & 02 & 02 & 01 & 00 & 00 & $112(44.8 \%)$ \\
\hline Higher secondary & 30 & 39 & 05 & 06 & 01 & 01 & 01 & 02 & 01 & 00 & $86(34.4 \%)$ \\
\hline Graduate & 08 & 16 & 02 & 02 & 00 & 01 & 01 & 00 & 01 & 00 & $31(12.4 \%)$ \\
\hline Post graduate & 02 & 02 & 01 & 01 & 01 & 00 & 00 & 00 & 00 & 00 & $07(2.8 \%)$ \\
\hline \multicolumn{12}{|l|}{ Profession } \\
\hline Garment workers & 69 & 87 & 06 & 13 & 02 & 03 & 02 & 01 & 02 & 01 & $186(74.4 \%)$ \\
\hline Security guard & 07 & 00 & 01 & 00 & 00 & 00 & 00 & 00 & 00 & 00 & 08 (3.2\%) \\
\hline Govt. employee & 05 & 04 & 02 & 03 & 01 & 00 & 00 & 01 & 00 & 00 & $16(6.4 \%)$ \\
\hline Non-govt. employee & 12 & 15 & 01 & 01 & 00 & 01 & 02 & 00 & 01 & 00 & $33(13.2 \%)$ \\
\hline Business & 05 & 00 & 00 & 00 & 00 & 00 & 00 & 00 & 00 & 00 & $5(2 \%)$ \\
\hline Unemployed & 00 & 01 & 00 & 00 & 00 & 00 & 00 & 01 & 00 & 00 & $02(08 \%)$ \\
\hline \multicolumn{12}{|l|}{$\begin{array}{l}\text { Monthly income of } \\
\text { respondents (BDT) }\end{array}$} \\
\hline $0-3000$ & 00 & 01 & 00 & 00 & 00 & 00 & 00 & 00 & 00 & 00 & $01(0.4 \%)$ \\
\hline $3001-5000$ & 21 & 33 & 02 & 04 & 00 & 01 & 00 & 00 & 01 & 00 & $62(24.8 \%)$ \\
\hline $5001-10,000$ & 47 & 59 & 07 & 10 & 02 & 02 & 02 & 01 & 02 & 01 & $133(53.2 \%)$ \\
\hline $10,001-15,000$ & 14 & 18 & 00 & 03 & 01 & 00 & 01 & 00 & 00 & 00 & $37(14.8 \%)$ \\
\hline $15,001-20,000$ & 11 & 04 & 00 & 00 & 00 & 01 & 00 & 01 & 00 & 00 & 17 (6.8\%) \\
\hline $20,000+$ & 05 & 02 & 01 & 00 & 00 & 00 & 01 & 00 & 00 & 00 & 09 (3.6\%) \\
\hline \multicolumn{12}{|l|}{$\begin{array}{c}\text { Tenure of } \\
\text { migration (year) }\end{array}$} \\
\hline Less than 2 & 35 & 31 & 03 & 06 & & 01 & 01 & 02 & 01 & 00 & 80 (32\%) \\
\hline $2-5$ & 34 & 43 & 04 & 07 & 02 & 03 & 01 & 02 & 02 & 01 & 99 (39.6\%) \\
\hline $6-10$ & 19 & 18 & 02 & 03 & 00 & 00 & 00 & 00 & 01 & 00 & $43(17.2 \%)$ \\
\hline $10+$ & 10 & 15 & 01 & 01 & 00 & 00 & 01 & 00 & 00 & 00 & $28(11.2 \%)$ \\
\hline \multicolumn{12}{|l|}{$\begin{array}{c}\text { Number of family member } \\
\text { of respondent }\end{array}$} \\
\hline $2-3$ & \multicolumn{2}{|c|}{134} & \multicolumn{2}{|c|}{16} & \multicolumn{2}{|c|}{03} & \multicolumn{2}{|c|}{05} & \multicolumn{2}{|c|}{02} & $160(64 \%)$ \\
\hline $4-6$ & \multicolumn{2}{|c|}{62} & 10 & & & 4 & 0 & & & 2 & 79 (31.6\%) \\
\hline $7-10$ & 11 & & 01 & & & 0 & 0 & & & 0 & $12(4.8)$ \\
\hline $10+$ & 00 & & 00 & & & 0 & 0 & & & 0 & $00(0 \%)$ \\
\hline Grand total & 98 & 107 & 10 & 17 & 03 & 04 & 04 & 03 & 03 & 01 & $250(100 \%)$ \\
\hline
\end{tabular}

Source: field survey 2015. 
Table 2. Push factors for migration.

\begin{tabular}{|c|c|c|c|c|c|c|c|c|c|c|c|c|c|c|}
\hline \multirow{2}{*}{$\begin{array}{c}\text { Push factors } \\
\text { Sex }\end{array}$} & \multicolumn{2}{|c|}{$\begin{array}{c}\text { Political } \\
\text { instability } \\
(8.4 \%)\end{array}$} & \multicolumn{2}{|c|}{$\begin{array}{c}\text { Education } \\
(4.0 \%)\end{array}$} & \multicolumn{2}{|c|}{$\begin{array}{c}\text { Employment } \\
(44.8 \%)\end{array}$} & \multicolumn{2}{|c|}{$\begin{array}{c}\text { Communal } \\
\text { attack } \\
(14.0 \%)\end{array}$} & \multicolumn{2}{|c|}{$\begin{array}{c}\text { Tortured by law } \\
\text { enforcing agencies } \\
(5.6 \%)\end{array}$} & \multicolumn{2}{|c|}{$\begin{array}{c}\text { Lose of } \\
\text { ancestral land } \\
(19.6 \%)\end{array}$} & \multicolumn{2}{|c|}{$\begin{array}{c}\text { Intra-ethnic conflict } \\
(3.6 \%)\end{array}$} \\
\hline & M & $\mathrm{F}$ & M & $\mathrm{F}$ & M & $\mathrm{F}$ & $\mathrm{M}$ & $\mathrm{F}$ & $\mathrm{M}$ & $\mathrm{F}$ & M & $\mathrm{F}$ & M & $\mathrm{F}$ \\
\hline \multicolumn{15}{|l|}{$\begin{array}{c}\text { Ethnic } \\
\text { composition }\end{array}$} \\
\hline Chakma & 12 & 06 & 02 & 05 & 31 & 56 & 15 & 18 & 09 & 05 & 23 & 14 & 06 & 03 \\
\hline Marma & 01 & 01 & 01 & 02 & 05 & 10 & 01 & 01 & 00 & 00 & 02 & 03 & 00 & 00 \\
\hline Tripura & 00 & 00 & 00 & 00 & 02 & 02 & 00 & 00 & 00 & 00 & 01 & 02 & 00 & 00 \\
\hline Tanchangya & 01 & 00 & 00 & 00 & 02 & 02 & 00 & 00 & 00 & 00 & 01 & 01 & 00 & 00 \\
\hline Others & 00 & 00 & 00 & 00 & 01 & 01 & 00 & 00 & 00 & 00 & 02 & 00 & 00 & 00 \\
\hline \multicolumn{15}{|l|}{ Districts } \\
\hline Khagrachari & 05 & 02 & 01 & 03 & 18 & 20 & 07 & 08 & 04 & 02 & 06 & 07 & 01 & 01 \\
\hline Rangamati & 08 & 05 & 02 & 04 & 20 & 44 & 08 & 11 & 05 & 03 & 20 & 06 & 05 & 01 \\
\hline Bandarban & 01 & 00 & 00 & 00 & 03 & 07 & 01 & 00 & 00 & 00 & 03 & 07 & 00 & 01 \\
\hline Total & 14 & 07 & 03 & 07 & 41 & 71 & 16 & 19 & 09 & 05 & 29 & 20 & 06 & 03 \\
\hline Percentage & 5.6 & 2.8 & 1.2 & 2.8 & 16.4 & 28.4 & 6.4 & 7.6 & 3.6 & 2.00 & 11.6 & 8.00 & 2.4 & 1.2 \\
\hline
\end{tabular}

Source: field survey 2015.

grated to the study area due to communal attack, $8.4 \%$ for political instability. Side by side intra-indigenous conflicts in CHT recently have become an emerging reason for migration. 3.6\% respondents were migrated because of this continuous intra-ethnic conflict. Comparatively the male portion of the CHT indigenous peoples is afraid of becoming victim of the ongoing conflict between PCJSS (Parbatya Chattagram Jana Samhati Samity) and UPDF (United Peoples Democratic Front), the two ethnic political groups in the CHT. 5.6\% and 4.0\% are found migrated after being tortured by the law enforcing agencies and scarcity of educational facilities respectively.

\subsection{Pull Factors}

Some strong pull factors have attracted the indigenous peoples to this plain area (See Table 3). A large number of migrants have chosen this study area as destination because of its industrial infrastructure. $60 \%$ of the respondents shared that they have come to this area for employment purpose. Informants added that there are lots of readymade garments factories situated because of being an industrial area. It is a bit easier for less-skilled and unskilled labor to find out jobs like, security guard, garments worker and driver.

Respondents chose this area for living because they have available known persons at the zone. $24.4 \%$ respondents accounted that they had available known person (relatives, friends, villagers etc.) in this area before migration. Those known people provided shelter and other assistance before getting job. This network helps them to continue their migration.

Chittagong is the nearest industrialized area for the CHT peoples. According to the Ravenstein's law people try to migrate in low distance (Gautam, 2005: 06) which supports the flow of indigenous peoples' migration to this area. $7.2 \%$ shared that they live this place because it is very easy to come in this area from the CHT, easy to go back. So, they can stand beside their family in any problem. They can easily attend in any social festival or program in their area of origin.

Civic facilities of this urban area are considered as an encouraging factor of indigenous migration. The education system and health facilities attracted migrants. $4.4 \%$ of respondents identified that they have migrated because of educational facilities while $4.0 \%$ of them found migrated for health facilities.

To sum up it can be said that the cause of migration of indigenous peoples from hill to plain districts is mainly 
Table 3. Pull factors of migration.

\begin{tabular}{|c|c|c|c|c|c|c|c|c|c|c|}
\hline \multirow{2}{*}{$\begin{array}{c}\text { Pull factors } \\
\text { Sex ratio }\end{array}$} & \multicolumn{2}{|c|}{ Job facilities } & \multicolumn{2}{|c|}{ Good network } & \multicolumn{2}{|c|}{ Short distance } & \multicolumn{2}{|c|}{ Educational facilities } & \multicolumn{2}{|c|}{ Health } \\
\hline & $\begin{array}{c}\mathrm{M} \\
(25.2 \%)\end{array}$ & $\begin{array}{c}F \\
(34.8 \%)\end{array}$ & $\begin{array}{c}\mathrm{M} \\
(2.4 \%)\end{array}$ & $\begin{array}{c}F \\
(2 \%)\end{array}$ & $\begin{array}{c}\mathrm{M} \\
(12.8 \%)\end{array}$ & $\begin{array}{c}F \\
(11.6 \%)\end{array}$ & $\begin{array}{c}M \\
(4.4 \%)\end{array}$ & $\begin{array}{c}F \\
(2.8 \%)\end{array}$ & $\begin{array}{c}\mathrm{M} \\
(2.4 \%)\end{array}$ & $\begin{array}{c}F \\
(1.6 \%)\end{array}$ \\
\hline \multicolumn{11}{|l|}{$\begin{array}{c}\text { Ethnic } \\
\text { composition }\end{array}$} \\
\hline Chakma & 51 & 73 & 04 & 03 & 27 & 22 & 10 & 06 & 06 & 03 \\
\hline Marma & 06 & 09 & 01 & 01 & 03 & 05 & 00 & 01 & 00 & 01 \\
\hline Tripura & 02 & 03 & 00 & 01 & 01 & 00 & 00 & 00 & 00 & 00 \\
\hline Tanchangya & 02 & 02 & 01 & 00 & 01 & 01 & 00 & 00 & 00 & 00 \\
\hline Others & 02 & 00 & 00 & 00 & 00 & 01 & 01 & 00 & 00 & 00 \\
\hline \multicolumn{11}{|l|}{ Districts } \\
\hline Rangamati & 40 & 50 & 03 & 02 & 15 & 16 & 08 & 05 & 02 & 01 \\
\hline Khagrachari & 20 & 31 & 02 & 01 & 14 & 07 & 02 & 02 & 04 & 02 \\
\hline Bandarban & 03 & 06 & 01 & 02 & 03 & 06 & 01 & 00 & 00 & 01 \\
\hline Total & 63 & 87 & 06 & 05 & 32 & 29 & 11 & 07 & 06 & 04 \\
\hline$\%$ & \multicolumn{2}{|c|}{$60 \%$} & \multicolumn{2}{|c|}{$24.8 \%$} & \multicolumn{2}{|c|}{$7.2 \%$} & \multicolumn{2}{|c|}{$4.4 \%$} & \multicolumn{2}{|c|}{$4 \%$} \\
\hline
\end{tabular}

Source: field survey 2015.

for economic reasons. A large scale of indigenous peoples has been migrating internally to industrialized zone in order to earn hard-cash income and for economic solvency.

\section{Impacts of Migration}

This section concentrates on the overall consequences of internal migration of the CHT indigenous peoples. The data sheet shows that certain socio-cultural and demographic impacts on the indigenous peoples have been occurred due to migration from hill to plain districts (see Table 4). This section tries to analyze the demographic, social and cultural impacts of migration.

\subsection{Demographic Impacts}

There are various demographic impacts on migrant people in the study area. It is observed only a few percent people of migrant both male and female are old in age. The absence of aged people makes an imbalanced generation gap in the study area. Due to lack of aged and experienced population in the area, the ethnic norms and values have become faded. The most important demographic impact is low birth rate due to migration. Traditionally the indigenous society prefers extended family type, but this trend is changing in a large scale due to migration. It is noticed that the number of children is decreasing day by day in the responded family. $86.4 \%$ respondent reported they have children between 1 and 2. 90.8\% migrants reported they are living in single family. $87.2 \%$ of total respondent supported that single family is better in city life because of less income, poor housing condition and more expenses. Breaking in traditional family structure changes social ties, norms and values.

\subsection{Social and Cultural Impacts}

The most important impact of internal migration is noticed on socio-cultural life of indigenous peoples. The change of traditional food habit is one of the major impacts on the indigenous culture. The indigenous peoples have a distinct food habit which based on Jum cultivation and on hilly landscape in the CHT. The food habit has been changing due to migration in plain areas. $65.2 \%$ of total respondents reported their food habit is changing for internal migration. The frequency of having Jum food has been reduced after being migrated from CHT. Only 15.2\% respondent reported that they consume Jum food in everyday meals. 
Table 4. Impacts on migrant indigenous peoples.

\begin{tabular}{|c|c|c|}
\hline Changes in food habit for migration & $\mathrm{N}=\mathbf{2 5 0}$ & $\%$ \\
\hline \multicolumn{3}{|l|}{ Using of nappi $^{5}$ in carry cooking } \\
\hline Yes & 187 & $74.8 \%$ \\
\hline No & 63 & $25.2 \%$ \\
\hline \multicolumn{3}{|l|}{ Cooking carry by bamboo tube } \\
\hline Yes & 59 & $23.6 \%$ \\
\hline No & 191 & $76.4 \%$ \\
\hline \multicolumn{3}{|l|}{ Frequency of having Jum food } \\
\hline Daily & 38 & $15.2 \%$ \\
\hline Once in a week & 74 & $29.6 \%$ \\
\hline Once in a month & 56 & 22.4 \\
\hline Once in year & 82 & $32.8 \%$ \\
\hline \multicolumn{3}{|c|}{ Changes in dress-up pattern } \\
\hline \multicolumn{3}{|l|}{ Use traditional dress } \\
\hline Yes & 196 & $78.4 \%$ \\
\hline No & 54 & $21.6 \%$ \\
\hline \multicolumn{3}{|l|}{ Frequency of using traditional dress } \\
\hline Only in house & 73 & $29.2 \%$ \\
\hline Occasionally in house & 68 & $27.2 \%$ \\
\hline Occasionally in public place & 39 & $15.6 \%$ \\
\hline Always in Public place & 16 & $6.4 \%$ \\
\hline \multicolumn{3}{|l|}{ Dress wear in weeding ceremony } \\
\hline Traditional dress & 94 & $37.6 \%$ \\
\hline Non-traditional dress & 145 & $58 \%$ \\
\hline Others & 11 & $4.4 \%$ \\
\hline \multicolumn{3}{|l|}{ Changes in using language for communication } \\
\hline Language used maximum time in a day & 108 & $43.2 \%$ \\
\hline Mother tongue & 142 & $56.8 \%$ \\
\hline \multicolumn{3}{|l|}{ Bangla } \\
\hline language used with family members & 221 & $88.4 \%$ \\
\hline Mother tongue & 29 & $11.6 \%$ \\
\hline \multicolumn{3}{|c|}{ Bangla } \\
\hline \multicolumn{3}{|c|}{ Children' use of mother tongue as medium of communication } \\
\hline Yes & 198 & $79.2 \%$ \\
\hline No & 52 & $20.8 \%$ \\
\hline \multicolumn{3}{|l|}{ Family types } \\
\hline Single & 227 & $90.8 \%$ \\
\hline Extended & 23 & $9.2 \%$ \\
\hline \multicolumn{3}{|l|}{ No. of Children } \\
\hline $1-2$ & 216 & $86.4 \%$ \\
\hline $3-4$ & 27 & $10.8 \%$ \\
\hline $5-6$ & 07 & $2.8 \%$ \\
\hline \multicolumn{3}{|l|}{ Participation in indigenous social festival } \\
\hline Yes & 214 & $85.6 \%$ \\
\hline No & 36 & $14.4 \%$ \\
\hline
\end{tabular}

Source: field survey 2015.

Cooking curry using bamboo tube is one of the most favorite cooking system in indigenous society. The rate of cooking carry by bamboo has alarmingly decreased. $76.4 \%$ of total migrants do not use this traditional cook${ }^{5}$ Paste of dry fish. 
ing system due to lack of cooking instrument. Having boiled food (without oil and spice) has also decreased. As the data shows using oil in cooking has increased extremely, $48.4 \%$ of total respondents noted it. Collected data shows the dependency on fast food has been increased moderately.

The indigenous peoples' traditional dress-up pattern drastically differs from the mainstream people of Bangladesh. The decrease in the use of traditional dress is alarming for their identity and distinctiveness. $21.6 \%$ of total respondents reported they do not totally use their traditional dress. From the rest proportions of respondent $29.2 \%$ use traditional dress only when they stay in house while $27.2 \%$ use their traditional dress occasionally. $58 \%$ of total respondent marked that they put on non-traditional dress in the occasion of their wedding ceremony.

Usage of own mother language is also facing extinction after migration in plain land. The migrant indigenous peoples can't use their own language. Moreover, indigenous languages have been mixed with Bangle and English words. 6.8\% migrants use Bangla as official language most of the time in a day. On the other hand, $11.6 \%$ respondents reported that they use Bangla language with family members in house and $20.8 \%$ children do not use mother tongue as a medium of communication.

Drinking homemade alcohol in social festival is a part of culture of indigenous society. Serving homemade alcohol to any new guest is a matter of honor in the CHT region. Mass adult people drink this alcohol to get relaxed from workload. But many young migrants in this area are observed getting addicted of drinking alcohol.

\section{Conclusion}

The indigenous peoples are marked as most peripheral community in the modern world system. Because of having social institution, legal system and cultural pattern different from the dominant class of society, they are considered most vulnerable minority in a country. There have approximately 45 indigenous groups, 14 from CHT and 31 from plain districts, been living in Bangladesh for centuries. Migration, among various causes, is one of the most important issues continuously affecting on overall livelihoods of indigenous peoples in Bangladesh. This study aims at to find out the causes and impacts of internal migration of CHT indigenous peoples. The major findings of the work is internal migration has been occurring mainly due to economic and political reasons and it keep impacts on the social, cultural and demographic lives of indigenous peoples in terms of birth rates, food habit, language and traditional dress. It has become a common phenomenon that internal migration makes changes in social structure, community ties and traditional norms-values.

\section{References}

Chakma, M. K. (2009). Brief History and Struggle of CHT. Rangamati: JSS. http://www.pcjss-cht.org/cht-history-strugle/

Chowdhury, M. S., \& Chakma, P. (2015). Human Rights Report 2014 on Indigenous Peoples in Bangladesh. Dhaka: Kapaeeng Foundation.

Gautam, T. R. (2005). Causes and Impact of Migration: A Sociological Study of Emigration from Kandebash, Baglung, Nepal. http://www.nepjol.info/index.php/DSAJ/article/view/285

Giddens, A. (2006). Sociology. New York: Polity Press.

Mohsin, A. (1997). The Politics of Nationalism: The Case of Chittagong Hill Tracts, Bangladesh. Dhaka: UPL.

PCJSS (2013). Reports on Implementation of Chittagong Hill Tracts Peace Accord. Rangamati: Information and Publicity Department of PCJSS. 